International Journal of Civil Engineering and Technology (IJCIET)

Volume 9, Issue 10, October 2018, pp. 234-241, Article ID: IJCIET_09_10_024

Available online at http://www.iaeme.com/ijciet/issues.asp?JType=IJCIET $\&$ VType=9\&IType $=10$

ISSN Print: 0976-6308 and ISSN Online: 0976-6316

(C) IAEME Publication

Scopus Indexed

\title{
PRUNING TEST AND ENCLOSURE FERTILIZER FOR GROWTH AND PRODUCTION TECHNOLOGY OF SALIBU RICE
}

\author{
Marahadi Siregar, Sulardi, Samrin, Rusiadi, Abdi Setiawan, Andysah Putera Utama \\ Siahaan, Ismail D and Devi Andriani Luta
}

Universitas Pembangunan Panca Budi., Medan, Indonesia

\begin{abstract}
Rice is an important food crop in Indonesia. This condition encourages the need to increase national rice production. Increased national rice productivity is also needed to reduce rice imports and achieve resilience and self-sufficiency. The effort to increase national rice production is Salibu rice cultivation. This study uses a splitsplit plot design with an area plot of $1 \mathrm{~m} \times 1 \mathrm{~m}$, whereas the main plot is the organic rice booster formula from the stem trimmed $15 \mathrm{~cm}(B)$ and the stem trimmed $30 \mathrm{~cm}$ $(N)$. Organic cow manure (B1), organic goat manure (B2), chicken organic manure (B3) and not given (NB) as subplots while three rice varieties, Ciherang, Mekongga and Inpara as subplots.. The parameters observed for the potential of each production variety in each plot of all treatments (ton/ha) included the number and weight of grain and rice growth including plant height, panicle length, and some tillers. From the results of preliminary research that the weight production of plotted grain has a very significant effect on the V2 Cavity Variety (213.46). For V3 Veritas V3 has a genuine effect on V2 Vascularity. Parameters of Grain Weight Perplot after statistical tests showed that the treatment of Chiherang V1 variety $(870.63 \mathrm{gr})$ had no significant effect on Variety V3 (872.08 gr), but it was the very significant effect on Void Cavity V2 (901.63 g). For V3, it has a genuine effect on V2 Vascularity.
\end{abstract}

Keywords: organic fertilizer, rice cultivation, manure

Cite this Article: Marahadi Siregar, Sulardi, Samrin, Rusiadi, Abdi Setiawan, Andysah Putera Utama Siahaan, Ismail D and Devi Andriani Luta, Pruning Test and Enclosure Fertilizer for Growth and Production Technology of Salibu Rice, International Journal of Civil Engineering and Technology, 9(10), 2018, pp. 234-241.

http://www.iaeme.com/IJCIET/issues.asp?JType=IJCIET\&VType=9\&IType $=10$ 


\section{INTRODUCTION}

Rice is Indonesia's staple food crop. This condition encourages the need for an increase in national rice production. National rice productivity increases are also needed to reduce rice imports and achieve food security and independence [1]-[3]. One effort to increase national rice production is by cultivating Salibu rice. It is a rice plant which is a bud that grows from stems that have been harvested and produces new tillers that can be harvested. In general, new shoots will appear on the nearest segment of the former cut, approximately three days after the rice stem is cut. Salted rice is not like transplanting rice [4]-[6]. In general, the growth and maturity rate of Salibu rice is not uniform, and the yield obtained is lower compared to the main crops (transplanting) [7]. However, with better cultivation techniques, Salibu rice production can be increased, and more benefits can also be achieved. Genetically reported local rice that has a kinship with wild rice species has the characteristics of Salibu and secondary tillers. Salibu or in the local language often referred to as Singgang or Turiang is a seedling of rice that grows back after being harvested. The wild rice species Oryza Perennis Moench is the ancestor of Oryza Sativa L. which is widely found in Asia, especially in swampland habitats [8]-[11] This species has a perennial type with high rat potential and can produce a lot of vegetative growth. In resource constraints, this Ratun rice cultivation can be used as an alternative to increasing cropping index per year, for example from 1 time to 2 times or from 2 times to 3 times planting in one year [12]-[14] Some of the benefits of Salibu rice, among others, are: Without tillage, seeding, and planting again. Less labor needed, Time to reach a short harvest, less need for irrigation water. Production costs are cheaper. The technical requirements needed are in the area irrigation water is still available after the main crop is harvested, and irrigation can be appropriately managed [15]-[18].

\section{THEORIES}

Salibu technology is modified by utilizing the rice rootstock after harvest as a producer of shoots or tillers that can be nurtured and cultivated. Observations in Tanah Datar Regency, West Sumatra, which has applied this technology with proper fertilization and maintenance, the productivity of Salibu rice can reach 9.3 tons/ha, with an average of 6.5 to 8 tons/ha. Regarding increasing the cropping index, it is possible because it does not require soil treatment, nurseries, and planting so that it can save time, effort, and costs of operating significantly [19]. Salibu rice cultivation is one of the technological innovations to spur the productivity of wet rice as a staple food for the community. Factors that influence the cultivation of Salibu rice include cutting the remaining harvest stems, varieties, groundwater conditions after harvest, and fertilization [20]. Salibu rice is a rice plant that grows again after the remaining harvest stems are cut or trimmed, the shoots will emerge from books in the soil. These shoots will release new roots so that the nutrient supply is no longer dependent on the old stems; these shoots can divide or sprout again as rice moves usually, this is what makes the growth and production the same or higher than the first plant (mother). Salted rice is rice that grows from the rest of the harvest without cutting the stems; the shoot will appear in the uppermost book, the nutrient supply remains from the old stem. This cultivation can also indirectly overcome the limitations of superior varieties, because the next plant growth occurs vegetatively, the quality of the variety remains the same as the first plant [21].

The effort to increase the productivity of other rice plants is to fulfill their daily needs [22]. Fertilization aims to increase the nutrients needed by plants because nutrients contained in the soil are not always sufficient to optimally promote plant growth [23]-[26]. So far, farmers tend to use inorganic fertilizers continuously. The relatively high use of inorganic fertilizers can cause adverse impacts on the soil environment, thereby reducing the 
productivity of agricultural land [27]. These conditions lead to the idea of re-using organic material as a source of organic fertilizer. The use of organic fertilizer can maintain the balance of land and increase land productivity and reduce the environmental impact of the soil. Organic fertilizers are the result of decomposition of organic materials that are decomposed (transformed) by microbes, the result of which can provide nutrients needed by plants for plant growth and development. Organic fertilizer is essential as a buffer for soil physical, chemical and biological properties to improve fertilizer efficiency and land productivity [28]-[30].

\section{METHODOLOGY}

This research was carried out in Dusun VII Sukamaju Indah, Sukamaju Village, Sunggal Subdistrict, Deli Serdang Regency, North Sumatra Province with an altitude of $20 \mathrm{~m}$ above sea level and a distance from the beach $8 \mathrm{~km}$ and lasted from 2017. The material used in this study was rice varieties with evaluation of potential yield such as Ciherang, Mekongga, Inpara, organic fertilizer namely animal waste. The tools used in this study are hoe, sprayer, stakes, electroconductivity, ph meters, meters, stationery, and other tools that support the research. This study used a randomized block design group in which:

Factor I : $\quad$ 1. Trimming $10 \mathrm{~cm}(B) .2$. Trimming $20 \mathrm{~cm}(\mathrm{~N})$.

Factor II : $\quad$ 1. Cow manure (B1), 2. Goat Manure (B2) 3. Chicken Manure (B3)

Factor III : $\quad$ 1. Ciherang (V1) 2. Cavity (V2) 3. Inpara (V3).

The parameters observed are 1 . The growth of rice plants includes the length of the plant, number of tillers, panicle length 2 . Rice production includes the number of grain crops and grain weight.

\section{RESULT AND DISCUSSION}

The results of variance analysis were in the form of f-count and f-table 0.5 and 01 . Pruning Test and Giving Fertilizer for Growth and Salibu Rice Production for all observed parameters were not significantly different. The average plant height and number of tillers due to Pruning Test have no significant effect; it can be presented in the following table.

Table 1 Average Test of Batang Padi Pruning at 40 days

\begin{tabular}{|c|c|c|c|c|}
\hline Treatment & \multicolumn{2}{|c|}{ Plant Height (cm) } & \multicolumn{2}{c|}{$\begin{array}{c}\text { Number of tillers } \\
\text { (tillers) }\end{array}$} \\
\hline $\mathrm{B}=10 \mathrm{~cm}$ & 99.45 & $\mathrm{a}$ & 15.96 & $\mathrm{a}$ \\
\hline $\mathrm{N}=20 \mathrm{~cm}$ & 99.39 & $\mathrm{a}$ & 15.92 & $\mathrm{a}$ \\
\hline
\end{tabular}

Description: The number followed by the same letter in the same column shows no significant difference in the $5 \%$ direction (lower case)

After the statistical test that the difference in the height of the harvesting of the remaining stumps did not significantly affect plant height and number of tillers. The combination of Salibu cultivation system treatment with a cutting height of $10 \mathrm{~cm}(99.45 \mathrm{~cm})$ from the soil surface gave the highest yield among other treatments $20 \mathrm{~cm}(99.39 \mathrm{~cm})$. As for the number of tillers cutting $10 \mathrm{~cm}$ (15.96 tillers) at a cutting height of $20 \mathrm{~cm}$ (15.92). The results of the regression analysis of the treatment of cutting/pruning of the rest of the harvest of 40 days can be seen in the bar diagram as presented in the figure below. The average plant height and number of tillers after the Cage Fertilizer Giving Test has no significant effect; it can be presented in Table 2 below. 
Table 2 Average Rice Fertilization Test after Pruning at 40 days

\begin{tabular}{|c|c|c|c|c|}
\hline Treatment & \multicolumn{2}{|c|}{ Plant Height (cm) } & \multicolumn{2}{c|}{$\begin{array}{c}\text { Number of tillers } \\
\text { (tillers) }\end{array}$} \\
\hline B1 = Cattle Fertilizer & 99.47 & $\mathrm{a}$ & 15.83 & $\mathrm{a}$ \\
\hline B2 = Goat Cage Fertilizer & 99.39 & $\mathrm{a}$ & 15.92 & $\mathrm{a}$ \\
\hline B3 = Chicken Cage Fertilizer & 99.40 & $\mathrm{a}$ & 15.92 & $\mathrm{a}$ \\
\hline
\end{tabular}

Description: The number followed by the same letter in the same column shows no significant difference in the $5 \%$ direction (lower case)

After the statistical test that the difference in the height of the harvesting of the remaining stumps did not significantly affect plant height and number of tillers. The combination of the Salibu cultivation system treatment with the treatment of cow manure B1 $(99.47 \mathrm{~cm})$ gave the highest results among other treatments such as Chicken B2 manure $(40.00 \mathrm{~cm})$ and B2 Goat Manure (99.39). As for the number of tillers treated with B2 and B3 Cages (15.92 tillers) on B1 Fertilizer treatment (15.83).

\subsection{Variety Test}

The average plant height and number of tillers after the Variety Test have no significant effect; this can be presented in the following table.

Table 3 Average Rice Variance Test after Pruning at 40 days

\begin{tabular}{|c|c|c|c|c|}
\hline Treatment & \multicolumn{2}{|c|}{ Plant Height $(\mathbf{c m})$} & \multicolumn{2}{c|}{$\begin{array}{c}\text { Number of tillers } \\
\text { (tillers) }\end{array}$} \\
\hline V1 = Chiherang & 99.47 & $\mathrm{a}$ & 15.83 & $\mathrm{a}$ \\
\hline V2 = Mikongga & 99.39 & $\mathrm{a}$ & 15.92 & $\mathrm{a}$ \\
\hline V3 = Inpara & 99.40 & $\mathrm{a}$ & 15.92 & $\mathrm{a}$ \\
\hline
\end{tabular}

Description: The number followed by the same letter in the same column shows no significant difference at $5 \%$ (lower case)

After statistical tests that the treatment of variance did not significantly affect plant height and number of tillers. The combination treatment of Salibu cultivation system with V1 (99.47 $\mathrm{cm})$ varieties treatment gave the highest results among other treatments such as $\mathrm{v}(40.00 \mathrm{~cm})$ and Fertilizer V3 $(99.40 \mathrm{~cm})$ and V2 $(99.39 \mathrm{~cm})$. As for the number of tillers of V2 and V3 varieties (15.92 tillers) in V1 treatment (15.83).

\subsection{Pruning Test}

As a result of Pruning Test there was no significant effect on panicle length, the number of grains of heavy grains of rice grains and the weight of plotted grain, this can be presented in the following table.

Table 4 Average of Batang Padi Pruning Test at 90 days

\begin{tabular}{|c|c|c|c|c|c|c|c|c|}
\hline Treatment & \multicolumn{2}{|c|}{$\begin{array}{l}\text { Tassel Length } \\
\text { (cm) }\end{array}$} & \multicolumn{2}{|c|}{$\begin{array}{l}\text { Amount of } \\
\text { Grain }\end{array}$} & $\begin{array}{l}\text { Weight of } \\
\text { Grain } \\
\text { Samples }\end{array}$ & \multicolumn{3}{|c|}{$\begin{array}{c}\text { Grain Weight Perplot } \\
\text { (gr) }\end{array}$} \\
\hline \multicolumn{5}{|c|}{ Prunning } & & & & \\
\hline $\mathrm{B}=10 \mathrm{~cm}$ & 17.92 & A & 210.25 & A & 210.50 & A & 881.19 & $\mathrm{~A}$ \\
\hline $\mathrm{N}=20 \mathrm{~cm}$ & 18.03 & A & 210.92 & A & 210.89 & A & 881.72 & A \\
\hline
\end{tabular}

Description: The numbers followed by different letters in the same column show significant differences at the level of 5\% (lower case) and differ very significantly at the level of $1 \%$ (big break)

After the statistical test, the difference in cutting height of the remaining crop stumps did not significantly affect the panicle length and amount of sliced grain, weight of paddy slabs 
and grain weight per plot. The combination of the treatment system of Salibu cultivation at Malai Length with a cutting height of $10 \mathrm{~cm}(17.92 \mathrm{~cm})$ and cut $20 \mathrm{~cm}(18.03 \mathrm{~cm})$. In the parameter of Amount of Salted Grain with a cutting height of $10 \mathrm{~cm}$ (210.25 grain) and cutting of $20 \mathrm{~cm}$ (210.92 grain). In parameter weight of Persamper grain with cutting height $10 \mathrm{~cm}(210.50 \mathrm{gr})$ and cutting $20 \mathrm{~cm}$ (210.89 gr). On parameter of Grain Weight Perplot with cutting height $10 \mathrm{~cm}(881,19 \mathrm{gr})$ and cutting $20 \mathrm{~cm}(881,72)$.

\subsection{Fertilization Test}

Fertilization test had no significant effect on panicle length, the number of raw grains but very significantly different from the weight of paddy grains and the weight of plotted grain; this can be presented in the following table.

Table 5 Average Rice Fertilization Test after Pruning at 40 days

\begin{tabular}{|c|c|c|c|c|c|c|c|c|}
\hline Treatment & \multicolumn{2}{|c|}{$\begin{array}{c}\text { Tassel } \\
\text { Length } \\
(\mathrm{cm})\end{array}$} & $\begin{array}{l}\text { Amoun } \\
\text { Grai }\end{array}$ & & \multirow[t]{2}{*}{$\begin{array}{c}\text { Weight } \\
\text { of Grain } \\
\text { Samples } \\
\text { (gr) }\end{array}$} & \multicolumn{3}{|c|}{$\begin{array}{c}\text { Grain Weight Perplot } \\
\text { (gr) }\end{array}$} \\
\hline \multicolumn{8}{|c|}{ Pemupukan } & \\
\hline B1 = Cattle Fertilizer & $\begin{array}{c}17.9 \\
2\end{array}$ & A & 210.75 & A & 210.88 & A & 878.83 & $\mathrm{~A}$ \\
\hline B2 = Goat Cage Fertilizer & $\begin{array}{c}17.9 \\
2\end{array}$ & $\mathrm{~A}$ & 210.29 & A & 210.71 & A & 881.08 & A \\
\hline B3 = Chicken Cage Fertilizer & $\begin{array}{c}17.9 \\
6\end{array}$ & A & 210.42 & A & 210.50 & A & 882.46 & $\mathrm{~A}$ \\
\hline
\end{tabular}

Description: The numbers followed by different letters in the same column show significant differences at the level of 5\% (lower case) and differ very significantly at the level of $1 \%$ (big break)

After statistical tests that fertilization treatment did not significantly affect the panicle length, the number of grain grains, the weight of rice paddy and the weight of grain plots. The combination of Salibu cultivation system parameters, panicle length treatment with the treatment of B1 cow manure $(17.92 \mathrm{~cm})$, goat manure B2 $(17.92 \mathrm{~cm}), \mathrm{B} 3$ chicken manure $(17.96 \mathrm{~cm})$. In the parameters of the number of grain with the treatment of giving B1 cow manure (210.75 grain), goat B2 manure (210.29 grain), B3 chicken manure (210.42 grain). For the parameters of the weight of the paddy sample with the treatment of giving cow manure B1 (210.88 g), goat manure B2 (210.71 g), B3 chicken manure $(210.50 \mathrm{~g})$ and the weight parameters of plots with treatment of manure B1 cow $(878.83 \mathrm{gr})$, goat manure B2 (881.08 gr), B3 chicken manure (882.46 gr).

\subsection{Variety Test}

Average panicle length, number of permalai grain, grain weight of sample and weight of paddy plot due to pruning test had no significant effect on panicle length and number of unripe grain but very significantly different from the weight of paddy grain and weight of plotted grain, this can be presented in table 6 below. 
Table 6 Average Rice Variety Test after Pruning at 40 days

\begin{tabular}{|c|c|c|c|c|c|c|c|c|}
\hline Treatment & \multicolumn{2}{|c|}{$\begin{array}{c}\text { Tassel } \\
\text { Length } \\
\text { (cm) }\end{array}$} & \multicolumn{2}{|c|}{$\begin{array}{c}\text { Amount of } \\
\text { Grain }\end{array}$} & $\begin{array}{l}\text { Weight of } \\
\text { Grain } \\
\text { Samples } \\
\text { (gr) }\end{array}$ & \multicolumn{3}{|c|}{$\begin{array}{c}\text { Grain Weight Perplot } \\
\text { (gr) }\end{array}$} \\
\hline \multicolumn{5}{|c|}{ Variety } & & & & \\
\hline $\mathrm{V} 1$ = Chiherang & $\begin{array}{c}17.9 \\
2\end{array}$ & A & 210.75 & A & 209.21 & $\mathrm{C}$ & 870.63 & $\mathrm{C}$ \\
\hline $\mathrm{V} 2=$ Mikongga & $\begin{array}{c}17.9 \\
2\end{array}$ & A & 210.29 & A & 213.46 & A & 901.67 & A \\
\hline V3 = Inpara & $\begin{array}{c}17.9 \\
6\end{array}$ & A & 210.42 & A & 209.42 & $\mathrm{BC}$ & 872.08 & $\begin{array}{l}\text { B } \\
\text { C }\end{array}$ \\
\hline
\end{tabular}

Description: The numbers followed by different letters in the same column show significant differences at the level of 5\% (lower case) and differ very significantly at the level of $1 \%$ (big break)

The panicle length parameters and the number of moth grain after statistical tests showed that the treatment of Chiherang V1 variety $(17.92 \mathrm{~cm})$ had no significant effect on the Void Cavity Variety $(17.96 \mathrm{~cm})$ and V3 $(17.92 \mathrm{~cm})$ For the parameter of the number of Chiherang V1 varieties (210.75 grains) of variety grain which has no significant effect on the V2 Vascularity Variety (210.29 grain) and Impara V3 210.42). On the parameter of Grain Weight Samples and weight of plotted grain after statistical tests showed that the treatment of Chiherang V1 variance (209.21 gr) had no significant effect on V3 (209.42 gr) but the very significant effect on V2 Vascularity (213.46). For V3, it has a genuine effect on V2 Vascularity. Parameters of Grain Weight Perplot after statistical tests showed that the treatment of Chiherang V1 variety (870.63 gr) had no significant effect on V3 (872.08 gr), but it was the very significant effect on Void Cavity V2 (901.63 g). For V3, it has a genuine effect on V2 Vascularity.

\subsection{Plant height (cm) and number of tillers (tillers)}

The results of the study after statistical analysis showed that the treatment of rice stem pruning did not show any effect on all observed parameters. However, from the results of higher growth, number of tillers, panicle length, number of barley grain, grain weight per sample and weight of plotted grain at $10 \mathrm{~cm}$ cutting are best, presumably because the part is closer to the root which is the source of nutrient supply throughout the body plant. It results in regrowth after cutting. Among photosynthetic devices that are directly related to cutting and the resulting metabolic function are leaves. The re-growth of Orchard grass depends both on the carbohydrate reserves in the plant stems and on the leaf area remaining after pruning. The carbohydrates are needed to maintain metabolic activity during the initial stages of regrowth. Energy requirements for partial or complete regrowth can be supplied if there are enough stems or leaves left after pruning, to supply new leaves or tillers, which immediately become autotropic (self-generating energy) which will have an impact on production.

In the fertilization test in this study after the analysis was done in a statistic also did not show a real effect on all parameters observed. It is because the roots of plants have not appropriately utilized manure because it has not been completely decomposed. Giving manure in the water decomposes longer on the ground. The manure that is decayed is better than immature manure because more decayed manure contains high organic matter and the influence of nitrogen and microorganisms.

Plant height and number of tillers at 40 HST different varieties of rice are not real. This is thought to be variety V1 (varieties of ciherang), V2 (varieties of mekongga) and V2 (variants of inpara) where all three varieties have nearly the same genetic ability in developing other factors such as water, $\mathrm{CO} 2$, light, nutrients, and space-grabbing so in growth that is the 
increase in height size is not real. In the natural state of plant growth, it is largely determined by genetic factors of the plant itself, especially the condition of growth regulating substances (hormones). Ciherang variety data results showed higher plant growth because of genetically higher Ciherang varieties. In the weight parameters of paddy samples and the weight of grain, plots have a very significant effect on the variety planted. This is presumably, the difference in growth and yield of each variety in addition to genetic related to the plant itself, but also influenced by environmental factors. The internal factors of plant growth stimuli are in genetic control, but climatic, soil and biological elements such as pests, diseases, weeds and competition in obtaining nutrients that can affect growth and yield. Included in the availability of nutrients in the soil. It is suspected that plant growth is very much determined by the variety besides nutrients that are available in an optimum and balanced state. A plant will thrive if all the nutrients needed are sufficiently available for absorbing plants.

\section{CONCLUSION}

Ciherang varieties provide the best growth and yield compared to Mekanggo and Inpara varieties. The type of goat manure treatment is the best for the growth and yield of rice plants. There was no interaction between the types of manure and varieties on rice plants in all observed parameters.

\section{REFERENCES}

[1] S. Sharma and S. V. Patil, "Key indicators of rice production and consumption, correlation between them and supply-demand prediction," Int. J. Product. Perform. Manag., vol. 64, no. 8, pp. 1113-1137, Nov. 2015.

[2] E. J. Wailes, A. Durand-Morat, and M. Diagne, "Regional and National Rice Development Strategies for Food Security in West Africa," 2015, pp. 255-268.

[3] A. Sanusi et al., "GCG SIMULTANEITY EFFECTS, PROFIT MANAGEMENT AND VALUE OF INDONESIAN RETAIL COMPANIES,” Int. J. Civ. Eng. Technol., vol. 9, no. 7, pp. 1506-1518, 2018.

[4] T. Hutton, "Sodium Technological functions of salt in the manufacturing of food and drink products," Br. Food J., vol. 104, no. 2, pp. 126-152, Mar. 2002.

[5] A. Rachmat, S. Nugroho, D. Sukma, H. Aswidinnoor, and S. Sudarsono, "Overexpression of OsNAC6 transcription factor from Indonesia rice cultivar enhances drought and salt tolerance," Emirates J. Food Agric., vol. 26, no. 6, p. 519, 2014.

[6] S. Suroso et al., "Autoregression Vector Prediction on Banking Stock Return using CAPM Model Approach and Multi-Factor APT," Int. J. Civ. Eng. Technol., vol. 9, no. 9, pp. 1093-1103, 2018.

[7] M. S. Baloch, I. U. Awan, and G. Hassan, "Growth and yield of rice as affected by transplanting dates and seedlings per hill under high temperature of Dera Ismail Khan, Pakistan,” J. Zhejiang Univ. Sci. B, vol. 7, no. 7, pp. 572-579, Jul. 2006.

[8] Q. Zhang et al., "Eco-Physiological Responses of Rice (Oryza sativa L.) Roots to Zinc, Chromium Stress," in 2010 4th International Conference on Bioinformatics and Biomedical Engineering, 2010, pp. 1-4.

[9] A. Putra and M. Z. Ritonga, "Effectiveness duckweed (Lemna minor) as an alternative native chicken feed native chicken (Gallus domesticus)," IOP Conf. Ser. Earth Environ. Sci., 2018.

[10] W. S. Purba et al., "RELATIONSHIPS AMONG KNOWLEDGE, ATTITUDE AND BEHAVIORAL INTENTION OF WASTE MANAGEMENT TECHNOLOGY," Int. J. Civ. Eng. Technol., vol. 9, no. 9, pp. 792-798, 2018.

[11] H.-I. Oka and H. Morishima, "VARIATIONS IN THE BREEDING SYSTEMS OF A WILD RICE, ORYZA PERENNIS," Evolution (N. Y)., vol. 21, no. 2, pp. 249-258, Jun. 1967. 
[12] M. Mapegau, A. Paiman, and M. Marlina, "KARAKTER AGRONOMI PADI RATUN (ORIZA SATIVA. L) VARIETAS LOKAL PASANG SURUT TANJUNG JABUNG TIMUR,” J. Agroecotania Publ. Nas. Ilmu Budid. Pertan., vol. 1, no. 1, pp. 43-49, Jul. 2018.

[13] V. S. Nuzul, D. Indradewa, and D. Kastono, "Pengaruh Waktu dan Tinggi Pemotongan Tunggul terhadap Komponen Hasil dan Hasil Padi (Oryza sativa L.) Ratun," Vegetalika, vol. 7, no. 2, p. 54, May 2018.

[14] T. Eddy, B. Alamsyah, S. Aryza, and A. P. U. Siahaan, "An Effect Phenomena Circle Living Field in Secanggang Langkat," Int. J. Civ. Eng. Technol., vol. 9, no. 7, pp. 15751580, 2018.

[15] G. Muthanna and M. S. M. Amin, "Irrigation planning using geographic information system," Manag. Environ. Qual. An Int. J., vol. 16, no. 4, pp. 347-361, Aug. 2005.

[16] M. D. T. P. Nasution, Y. Rossanty, A. P. U. Siahaan, and S. Aryza, "The Phenomenon of Cyber-Crime and Fraud Victimization in Online Shop," Int. J. Civ. Eng. Technol., vol. 9, no. 6, pp. 1583-1592, 2018.

[17] M. D. T. P. Nasution, Y. Rossanty, P. B. Sari, and A. P. U. Siahaan, "Online Shoppers Acceptance: an Exploratory Study,” Int. J. Civ. Eng. Technol., vol. 9, no. 6, pp. 793-799, 2018.

[18] Y. Rossanty, S. Aryza, M. D. T. P. Nasution, and A. P. U. Siahaan, "Design Service of QFC And SPC Methods in the Process Performance Potential Gain and Customers Value in a Company," Int. J. Civ. Eng. Technol., vol. 9, no. 6, pp. 820-829, 2018.

[19] A. Harahap, Tiga Cara Optimalisasi Lahan Sawah. Badan Penyuluhan dan Pengembangan Sumberdaya Manusia Pertanian. Riau: Kementerian Pertanian, 2014.

[20] J. G. Alvarez Herrera, L. P. Pinzón Gómez, and J. E. Vélez, "Growth and Production of rice (oryza sativa 1.) under different fertilization plans with Silicon,” Ing. e Investig., vol. 37, no. 1, p. 7, Jan. 2017.

[21] M. Khalid Bashir and Y. Mehmood, "Institutional credit and rice productivity: a case study of District Lahore, Pakistan," China Agric. Econ. Rev., vol. 2, no. 4, pp. 412-419, Nov. 2010.

[22] K. A. Mottaleb, D. B. Rahut, and A. K. Mishra, "Modeling rice grain-type preferences in Bangladesh,” Br. Food J., vol. 119, no. 9, pp. 2049-2061, Sep. 2017.

[23] G. Gribaldi, N. Nurlaili, N. Dewi, E. Danial, F. Sakalena, and R. A. Suwignyo, "Modified Application of Nitrogen Fertilizer for Increasing Rice Variety Tolerance toward Submergence Stress,” Int. J. Agron., vol. 2017, pp. 1-6, 2017.

[24] A. I. F. Lubis et al., "Strategy for Improving Science and Welfare Through Community Empowerment Technology," Int. J. Civ. Eng. Technol., vol. 9, no. 9, pp. 1036-1046, 2018.

[25] Rusiadi et al., "Dependence of poverty dependence on Indonesian economic fundamentals: Sfavar approach,” Int. J. Civ. Eng. Technol., vol. 9, no. 6, 2018.

[26] A. K. Singh and R. L. Shrivastava, "Critical success factors of rice mills located in a cluster,” Int. J. Product. Perform. Manag., vol. 62, no. 6, pp. 616-633, Jul. 2013.

[27] F. Rahman, M. M. Rahman, G. K. . M. Rahman, M. A. Saleque, A. T. . S. Hossain, and M. G. Miah, "Effect of organic and inorganic fertilizers and rice straw on carbon sequestration and soil fertility under a rice-rice cropping pattern," Carbon Manag., vol. 7, no. 1-2, pp. 41-53, Mar. 2016.

[28] I. N. Y. Supartha, G. Wijana, and G. M. Andyana, "Aplikasi jenis pupuk organik pada tanaman padi sistem pertanian organik," E J. Agroekoteknologi Trop., vol. 1, no. 2, pp. 98-106, 2012.

[29] S. Iwaishi, "Effect of Organic Fertilizer and Effective Microorganisms on Growth, Yield and Quality of Paddy-Rice Varieties," J. Crop Prod., vol. 3, no. 1, pp. 269-273, Jun. 2001.

[30] A. Ikhwan, M. Yetri, Y. Syahra, and J. Halim, "A Novelty of Data Mining for Promoting Education based on FP-Growth Algorithm," Int. J. Civ. Eng. Technol., vol. 9, no. 7, pp. 1660-1669, 2018. 